\title{
EFFECT OF DIETARY ENERGY AND WEANING WEIGHT ON NITROGEN BALANCE AND ENERGY METABOLIZABILITY OF PIGLETS
}

\section{EFEITO DA ENERGIA DA DIETA E DO PESO AO DESMAME SOBRE O BALANÇO DE NITROGÊNIO E METABOLIZABILIDADE DA ENERGIA DE LEITÕES}

\author{
Marcia de Souza Vieira ${ }^{1 *}$ \\ Marcelo Luiz Somensi ${ }^{2}$ \\ Anna Mikaela Batista ${ }^{1}$ \\ Victoria Yasmin Domingues ${ }^{1}$ \\ ${ }^{1}$ Universidade Federal do Paraná, Curitiba, PR, Brazil. \\ 2Universidade Federal do Rio Grande do Sul, Porto Alegre, RS, Brazil. \\ "Corresponding author - msvzootec@yahoo.com.br
}

\begin{abstract}
This study aimed to evaluate the effects of dietary metabolizable energy (ME; 3.40, 3.60, or 3.80 Mcal $/ \mathrm{kg}$ ) and weaning weight (WW; $4.5 \pm 0.4$ and $6.7 \pm 0.5 \mathrm{~kg}$ ) on nitrogen balance (NB) and gross energy metabolizability in weanling piglets. In total, 32 barrow piglets were individually housed in metabolic cages for $28 \mathrm{~d}$ in a $2 \times 3$ factorial arrangement with five barrows per treatment. Only light and 3.80 ME and heavy and 3.40 ME/kg treatments had six barrows per treatment each. The diets were formulated to maintain a constant nutrient to ME ratio. Nitrogen balance was evaluated in three periods through total collection of feces and urine. Heavy piglets had $14 \%$ greater $\mathrm{N}$ intake, absorption, and retention in starter and total periods $(\mathrm{P}<0.05)$. The increasing in the levels of dietary $\mathrm{ME}$ linearly augmented $\mathrm{N}$ intake, absorption, and retention during starter and total periods $(\mathrm{P}<0.05)$. The dietary ME levels linearly increased energy metabolizability in all periods $(\mathrm{P}<0.05)$. In conclusion, heavy weaned piglets had better efficiency in nitrogen retention. Besides, increasing dietary ME levels can improve the $\mathrm{N}$ retention and the metabolizability of dietary energy.
\end{abstract}

Keywords: energy metabolism; light piglet; retained nitrogen.

\section{Resumo}

Este estudo objetivou avaliar o efeito da energia metabolizável da dieta (EM; 3,40, 3,60 ou 3,80 Mcal/kg) e do peso ao desmame ( $\mathrm{PD} ; 4,5 \pm 0,4$ e $6,7 \pm 0,5 \mathrm{~kg}$ ) sobre o balanço de nitrogênio (BN) e a metabolizabilidade da energia de leitões. 32 leitões machos castrados foram alojados individualmente em gaiolas de metabolismo por $28 \mathrm{~d}$ em um arranjo fatorial $2 \times 3$ com cinco animais por tratamento, exceto os tratamentos leve e 3,80 Mcal $/ \mathrm{kg}$ EM e pesado e 3,40 Mcal $/ \mathrm{kg} \mathrm{EM}$, que tiveram 6 animais por tratamento. As dietas foram formuladas para manter constante a razão nutriente:energia. $\mathrm{O} B N$ foi avaliado em três períodos, via coleta total de fezes e urina. Leitões pesados apresentaram 14\% maior $\mathrm{N}$ ingerido, absorvido e retido no período inicial e total $(\mathrm{P}<0,05)$. Os níveis de $\mathrm{EM}$ aumentaram linearmente o $\mathrm{N}$ ingerido, absorvido e retido no período inicial e total $(\mathrm{P}<0,05)$. Em todos os períodos avaliados, a metabolizabilidade da energia aumentou linearmente com o aumento dos níveis de $\mathrm{EM}(\mathrm{P}<0,05)$. 
Conclui-se que leitões desmamados pesados apresentam melhor eficiência na retenção de N. Além disso, o aumento da EM da dieta melhora a retenção de $\mathrm{N}$ e a metabolizabilidade da energia da dieta.

Palavras-chave: leitão leve; metabolismo energético; nitrogênio retido.

Received on September 28th, 2017.

Accepted on November 28th, 2017.

\section{Introduction}

One of the most important zootechnical indexes used to estimate the efficiency of pig production system is the number of piglets/born/sow/year. The increase in the number of born piglets reduces the cost per housed sow, increasing the system profitability. Recent studies, however, have shown that increasing the number of piglets led to an increase in the number of stillborn piglets and to a low birth weight ${ }^{(1)}$; it is also negatively correlated with survival to weaning, pre-weaning daily gain, and mean weaning weight ${ }^{(2,3)}$.

The reasons of the poor growth performance of light piglets are still unclear; however they must be related to the intrauterine competition for nutrients ${ }^{(4,5)}$, which results in different degrees of restriction of embryo growth $^{(6,7)}$. At weaning, the factors related to the environmental, nutritional, management, and health status during the suckling period can also exacerbate the poor performance of light piglets from weaning to market weight.

As the energy intake is the main factor that limit the nutrient intake in weaning piglets, the starter diet is usually concentrated in energy and amino acid to guarantee a better growth performance and allow the maximum protein deposition. Besides, there is an ideal Lys to energy ratio that must be kept to allow a proper protein deposition ${ }^{(8,9)}$. Nevertheless, previous studies did not show any performance improvement when dietary energy density was increased ${ }^{(10-12)}$, but greater body fat deposition was observed ${ }^{(12)}$.

The effect of weaning weight and dietary energy concentration, to understand the relationship of these factors, on the ability of weaning piglets to use the nitrogen and dietary energy has been little investigated. Therefore, the objective of this study was to evaluate the effect of the dietary energy concentration and weaning weight on nitrogen balance and energy metabolizability in order to determine if there is any interaction between these factors; in other words, if light piglets at weaning could improve the nitrogen retention and metabolizability of energy when fed an energy-nutrient-dense diet when compared with heavy piglets at weaning.

\section{Material and Methods}

The experiment was conducted at the Laboratório de Ensino Zootécnico of Universidade Federal do Rio Grande do Sul (UFRGS), located in Porto Alegre. All procedures used in this experiment were approved by the Ethics Committee on Animal Use from UFRGS (Protocol N. 21121).

Thirty-two weaning barrows (21-24 $\mathrm{d}$ of age) housed in individual metabolism crates were assigned to weaning weight (WW; light: $4.5 \pm 0.4 \mathrm{~kg}$ and heavy: $6.7 \pm 0.5 \mathrm{~kg}$ ) and metabolizable energy (ME: 3.40 , 3.60 , and $3.80 \mathrm{Mcal} / \mathrm{kg}$ ) in a $2 \times 3$ factorial treatment arrangement with five barrows per treatment, except light and 3.80 ME and heavy and 3.40 ME/kg treatments, which had six barrows per treatments. Piglets 
were categorized to light and heavy at the commercial facility. Metabolism crates $\left(0.48 \mathrm{~m}^{2}\right)$ were located in an environmental-controlled room and equipped with a feeder and a drinker. The experiment was conducted in two nursery phases: I, between 0 and $14 \mathrm{~d}$ after weaning; and II, between 15 and $28 \mathrm{~d}$ after weaning. Piglets were offered access to feed and water ad libitum throughout the study.

Diets with three ME levels were formulated (3.40, 3.60, or $3.80 \mathrm{Mcal} / \mathrm{kg}$ ) and fed as mash (Table 1). The control diet (3.40 Mcal ME/kg) was formulated with standard energy and nutrient recommendations ${ }^{(13)}$, whereas indispensable and dispensable amino acid, calcium, phosphorus, and lactose levels in the diets 3.60 and $3.80 \mathrm{Mcal} / \mathrm{kg}$ were adjusted for the increased ME. Ratios of 4.14 and $3.91 \mathrm{~g}$ of digestible Lys/Mcal of ME and 14.8\% and 8.5\% lactose were supplied in phases I and II, respectively. Milk replacers and swine plasma were added to stimulate feed intake and to ensure that diet digestibility was high. Piglets were given a pre-starter diet during the first $14 \mathrm{~d}$ and a starter diet during the subsequent $14 \mathrm{~d}$ of the experiment.

During feeds manufacture, five samples of each diet were collected, pooled, mixed, and sampled to achieve a $500 \mathrm{~g}$ of feed. All samples were stored at $-20{ }^{\circ} \mathrm{C}$ until required for analysis. The feed samples were analyzed in two replications for their proximate composition ${ }^{(14)}$. The digestibility assay consisted of seven days of adaptation, during phase I, followed by total fecal and urine collection for seven and $14 \mathrm{~d}$ during phases I and II, respectively.

Feces and urine collection was performed once a day. Ferric oxide at $0.1 \%$ was used as a marker just before the first and last meal to establish the exact period of feces collection ${ }^{(15)}$. Feces were weighed daily then

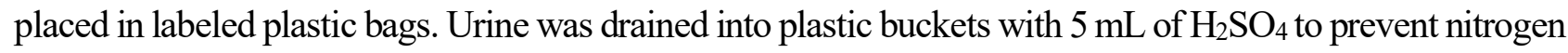
(N) loss. The volume was weighed daily, and the entire volume was kept in freezers at $-15^{\circ} \mathrm{C}$ until analysis. Fecal and urine samples were subsequently thawed and homogenized for the collection of two subsamples weighing $500 \mathrm{~g}$ and $100 \mathrm{~mL}$ per replicate, respectively, for analyses.

Feed and feces samples were ground in a knife mill with a $1 \mathrm{~mm}$ mesh (Model EDB-5, DeLeo Equipamentos Laboratoriais, Porto Alegre, Brazil). Dry matter (DM) in feces samples was determined by pre-drying of the samples in a forced-flow stove at $60{ }^{\circ} \mathrm{C}$ until constant weight and subsequent drying at $105{ }^{\circ} \mathrm{C}$ for1 $2 \mathrm{~h}$ (method: 930.15). Nitrogen content was determined in the dry material according to the Micro- Kjeldhal (method: 954.01; adapted by Prates ${ }^{(16)}$; model TE036/2; Tecnal, Piracicaba-SP, Brazil). Crude protein was calculated as nitrogen $x$ 6.25. The gross energy (GE) was determined by pressurized combustion with oxygen in an adiabatic bomb calorimeter (Model C2000 - IKA Werke GmbH\&Co. KG, Staufen, Germany). Benzoic acid (6318 kcal/kg) was used as the standard for calibration and was determined to be $631,772 \mathrm{kcal} / \mathrm{kg}$ at assay. Urine samples were dried in a forced-ventilation oven at $60{ }^{\circ} \mathrm{C}$ for $72 \mathrm{~h}$ (method: 930.15) and analyzed for GE content as described above. Urinary nitrogen was determined in the liquid sample (method: 984.13) as described above. All analyses were performed in duplicate, and the standard error (SE) between replicates was less than 5\% for all methods and less than $1 \%$ for energy.

Nitrogen balance and the coefficients of energy metabolizability was estimated as follows: Nitrogen intake $(\mathrm{g} / \mathrm{d})=$ feed intake $(\mathrm{g} / \mathrm{d}) \times(\% \mathrm{~N}$ diet $)$; Nitrogen absorbed $(\mathrm{g} / \mathrm{d})=\mathrm{N}$ intake $-\mathrm{N}$ feces; Nitrogen retained $(\%)$ $=(\mathrm{N}$ intake $-\mathrm{N}$ absorbed $)$. Energy metabolizability $(\%)=($ Gross energy intake - gross energy feces - gross energy urine)/gross energy intake) x 100 .

ANOVA was conducted using the Generalized Linear Model (GLM) procedure (SAS Institute, Inc. 1994, Cary, NC, USA), considering the main effects and the interactions between each of the two factors. Weaning age was included in the model as covariate. When the analysis of variance showed significant effects of ME levels, the sum of squares was broken down into linear or quadratic effect. Pooled SEM was calculated by 


\section{Results and Discussion}

There was no significant interaction between ME and WW for any of the evaluated responses. The hypothesis of this study was that light piglets fed a diet concentrated in energy and nutrients, especially lysine, were able to improve the utilization of $\mathrm{N}$ and dietary energy in relation to the heavy piglets due to a specific energy and nutrient requirements. However, the results refute our hypothesis. This can be observed due to the lack of interaction between weaning weight and ME levels for all evaluated responses.

There was no effect of WW on $\mathrm{N}$ balance responses in the pre-starter phase, only a trend to a higher $\mathrm{N}$ intake and absorption for heavy weaned piglets $(\mathrm{P}<0.10)$. These results may be an effect of an immature digestive system of these animals at that point, even for piglets that were weaned heavier. On the other hand, WW significantly influenced $\mathrm{N}$ balance in the starter and total period, with consequent improvement in the use of this nutrient but only for heavy animals. In fact, heavy weaned piglets presented 14\% higher intake, absorption, and retention $\mathrm{N}(\mathrm{P}<0.05)$, in the starter and total period. Weaning weight, however, had no effect on $\mathrm{N}$ in feces, urine, $\mathrm{N}$ ret/abs ratio or on energy metabolizability (Table 2). The $\mathrm{N}$ intake in light piglets is directly related to the lower values of the $\mathrm{N}$ absorbed and retained. This result may have been due to a limited intestinal physical capacity that prevents light piglets from increasing feed intake in relation to heavy piglets, as reported by Taylor et al. ${ }^{(17)}$. The lack of effect of WW on energy metabolizability was also observed by Arnaiz et al. ${ }^{(10)}$, who studied piglets weaned at 4.0 and $6.0 \mathrm{~kg}$, quite close to the WW range used in the present study.

The low capacity of light weaned piglets to take advantage of a nutrient-enriched diet may also be a reflection of their low birth weight and, consequently, a lower nutritional requirement in relation to heavy piglets. Previous studies ${ }^{(7,18)}$ report that WW is highly correlated with birth and slaughter weight. Many factors related to low birth weight may be related to a limitation of growth during the uterine phase. As observed by Paredes et al. ${ }^{(19)}$, light piglets had less muscularity in terms of total muscle fiber number and fiber area size. The number of fibers is related to the natal development ${ }^{(20)}$, whereas the fiber diameter is directly related to post-birth hypertrophy ${ }^{(21)}$. Thus, pigs with low fiber numbers and low capacity for hypertrophy would consequently have lower muscle mass and lower requirement of nutrients, so that nutritional manipulations, such as increased dietary energy or the maintenance of the lysine:energy ratio, would have no effect on the ability of light piglets to take advantage of dietary $\mathrm{N}$, as observed in this study. Jones et al. ${ }^{(22)}$ and Ribeiro et al. ${ }^{(23)}$ observed that heavy piglets deposit more protein and are more efficient at retaining nitrogen, supporting our results.

There was a linear effect of the dietary $\mathrm{ME}$ levels on $\mathrm{N}$ intake absorbed and retained at the starter and total phase $(\mathrm{P}<0.05)$, Table2. In all the evaluated periods, increasing dietary ME linearly increased metabolizability of energy $(\mathrm{P}<0.05)$, as shown in Table 2 . The linear regression of the ME levels against the $\mathrm{N}$ balance responses, in the total and starter phases, had a good fit $\left(\mathrm{r}^{2}>70 \%\right)$, with exception for $\mathrm{N}$ intake in the starter period $\left(\mathrm{r}^{2}=63 \%\right)$, as shown in Figure 1. For energy metabolizability, the $\mathrm{r}^{2}$ was higher than $88 \%$ in all evaluated periods (Figure 2).

The improvement on $\mathrm{N}$ retention and metabolizability as a function of increased dietary energy levels has also been observed in previous studies ${ }^{(10,12)}$. It may be related to the increased oil levels, used to raise ME levels, and with the increasing percentage of crude protein in the diets. The increase in oil 
may have increased the retention time in the digestive system, which allow more time for digestion and absorption to take place, resulting in the linear effect observed on these responses.

Table 2. Nitrogen balance and energy metabolizability according to the dietary| metabolizable energy and weaning weight ${ }^{1}$

\begin{tabular}{|c|c|c|c|c|c|c|c|c|c|}
\hline \multirow[b]{2}{*}{ Item } & \multicolumn{4}{|c|}{ ME, Mcal/kg } & \multicolumn{3}{|c|}{ WW, kg } & \multicolumn{2}{|c|}{ P-value } \\
\hline & 3.40 & 3.60 & 3.80 & SEM $^{2}$ & 6.7 & 4.5 & SEM & ME & WW \\
\hline Piglets, $\mathrm{n}$ & 11 & 10 & 11 & - & 16 & 16 & - & - & - \\
\hline \multicolumn{10}{|c|}{ Pre starter, 1 a $14 \mathrm{~d}$} \\
\hline $\mathrm{N}$ intake, $\mathrm{g} / \mathrm{d}$ & 19.14 & 18.30 & 19,81 & 1.26 & 20.30 & 17.87 & 1.29 & 0.403 & 0.072 \\
\hline $\mathrm{N}$ feces, $\mathrm{g} / \mathrm{d}$ & 3.24 & 2.78 & 2.87 & 0.22 & 3.17 & 2.75 & 0.23 & 0.307 & 0.278 \\
\hline $\mathrm{N}$ urine, $\mathrm{g} / \mathrm{d}$ & 1.71 & 2.04 & 2.05 & 0.22 & 1.97 & 1.89 & 0.23 & 0.472 & 0.837 \\
\hline $\begin{array}{l}\mathrm{N} \text { absorbed, } \\
\mathrm{g} / \mathrm{d}\end{array}$ & 15.90 & 15.52 & 16.94 & 0.68 & 17.13 & 15.11 & 0.69 & 0.329 & 0.090 \\
\hline $\begin{array}{l}\mathrm{N} \text { retained, } \\
\mathrm{g} / \mathrm{d}\end{array}$ & 14.19 & 13.49 & 14.89 & 0.70 & 15.16 & 13.22 & 0.71 & 0.389 & 0.113 \\
\hline $\mathrm{N}$ ret/abs & 0.89 & 0.87 & 0.88 & 0.01 & 0.88 & 0.88 & 0.01 & 0.428 & 0.785 \\
\hline Coef. $\mathrm{ME}^{3}, \%$ & 90.14 & 90.60 & 91.69 & 0.36 & 90.88 & 90.74 & 0.37 & 0.016 & 0.816 \\
\hline \multicolumn{10}{|c|}{ Starter (15 a $28 \mathrm{~d})$} \\
\hline $\mathrm{N}$ intake $\mathrm{e}^{3} \mathrm{~g} / \mathrm{d}$ & 25.28 & 30.26 & 29.62 & 1.28 & 30.65 & 26.12 & 1.28 & 0.021 & 0.048 \\
\hline $\mathrm{N}$ fec & 3.21 & 3.13 & 2.40 & 0.32 & 3.09 & 2.73 & 0.32 & 0.152 & 0.506 \\
\hline & 3.85 & 4.83 & 4.50 & 0.42 & 4.88 & 3.91 & 0.43 & 0.268 & 0.188 \\
\hline $\begin{array}{l}N \text { absorbed }{ }^{3}, \\
g / d\end{array}$ & 22.07 & 27.12 & 27.22 & 1.06 & 27.56 & 23.38 & 1.08 & 0.002 & 0.029 \\
\hline $\begin{array}{l}\mathrm{N} \text { retained }{ }^{3}, \\
\mathrm{~g} / \mathrm{d}\end{array}$ & 18.22 & 22.29 & 22.72 & 0.97 & 22.68 & 19.47 & 0.99 & 0.004 & 0.062 \\
\hline $\mathrm{N}$ ret/abs & 0.82 & 0.82 & 0.83 & 0.01 & 0.82 & 0.83 & 0.02 & 0.838 & 0.676 \\
\hline Coef. $\mathrm{ME}^{3}, \%$ & 87.40 & 87.97 & 90.93 & 0.45 & 88.93 & 88.60 & 0.47 & 0.000 & 0.671 \\
\hline \multicolumn{10}{|c|}{ Total period, 1 a $28 \mathrm{~d}$} \\
\hline $\mathrm{N}$ intake $3, \mathrm{~g} / \mathrm{d}$ & 23.24 & 26.27 & 26.35 & 0.99 & 27.20 & 23.37 & 1.01 & 0.052 & 0.030 \\
\hline & 3.22 & 3.01 & 2.56 & 0.27 & 3.12 & 2.74 & 0.28 & 0.214 & 0.415 \\
\hline $\mathrm{N}$ urine, $\mathrm{g} / \mathrm{d}$ & 3.14 & 3.90 & 3.69 & 0.31 & 3.91 & 3.24 & 0.32 & 0.224 & 0.216 \\
\hline $\begin{array}{l}\mathrm{N} \text { absorbed }{ }^{3}, \\
\mathrm{~g} / \mathrm{d}\end{array}$ & 20.01 & 23.26 & 23.79 & 0.79 & 24.08 & 20.63 & 0.81 & 0.004 & 0.017 \\
\hline $\begin{array}{l}\text { N retained }{ }^{3}, \\
g / d\end{array}$ & 16.88 & 19.36 & 20.11 & 0.72 & 20.17 & 17.39 & 0.73 & 0.008 & 0.031 \\
\hline $\mathrm{N}$ ret/abs & 0.84 & 0.85 & 0.84 & 0.01 & 0.84 & 0.85 & 0.01 & 0.787 & 0.899 \\
\hline Coef. $\mathrm{ME}^{3}, \%$ & 88.77 & 89.28 & 91.31 & 0.26 & 89.91 & 89.67 & 0.27 & 0.000 & 0.600 \\
\hline
\end{tabular}



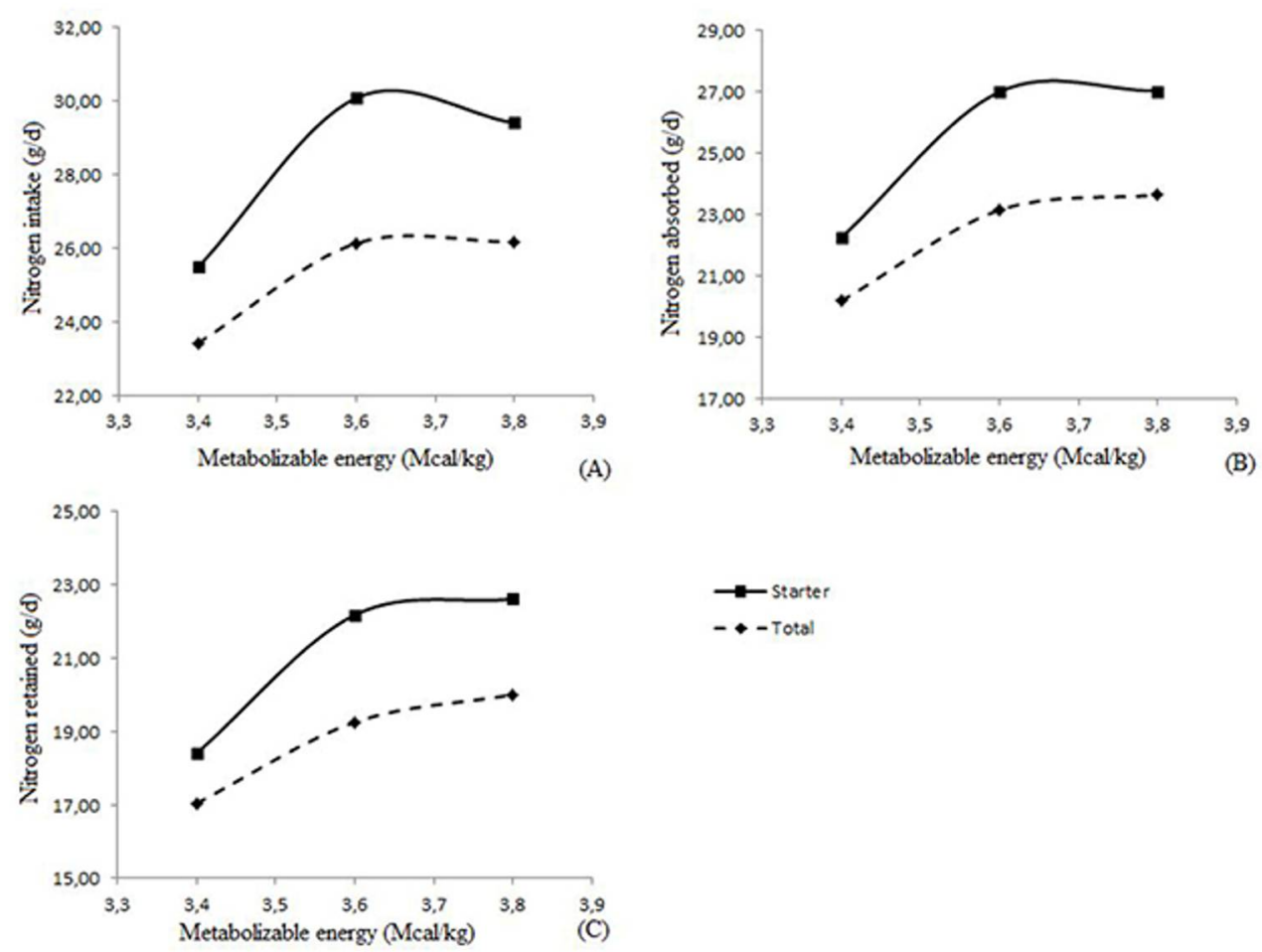

Figure 1. Linear effect of the dietary metabolizable energy levels on nitrogen intake (A; $\left.\mathrm{Y}_{\text {starter }}=9.80 \mathrm{x}-6.96\left[\mathrm{r}^{2}=0.63\right] ; \mathrm{Y}_{\text {total }}=6.87 \mathrm{x}-0.51\left[\mathrm{r}^{2}=0.76\right]\right)$ absorbed $\left(\mathrm{B} ; \mathrm{Y}_{\text {stater }}=\right.$ $\left.11.95 \mathrm{x}-17.59\left[\mathrm{r}^{2}=0.75\right] ; \mathrm{Y}_{\text {total }}=8.64 \mathrm{x}-8.79\left[\mathrm{r}^{2}=0.86\right]\right)$ and retained $\left(\mathrm{C} ; \mathrm{Y}_{\text {starter }}=-\right.$ $\left.10.50 \mathrm{x}-16.73\left[\mathrm{r}^{2}=0.83\right] ; \mathrm{Y}_{\text {total }}=7.40 \mathrm{x}-7.87\left[\mathrm{r}^{2}=0.92\right]\right)$. Each point represents the mean of 11 piglets for the levels 3.40 and $3.80 \mathrm{Mcal} / \mathrm{kg}$ and 10 piglets for the level 3.60 $\mathrm{Mcal} / \mathrm{kg} \mathrm{EM}$

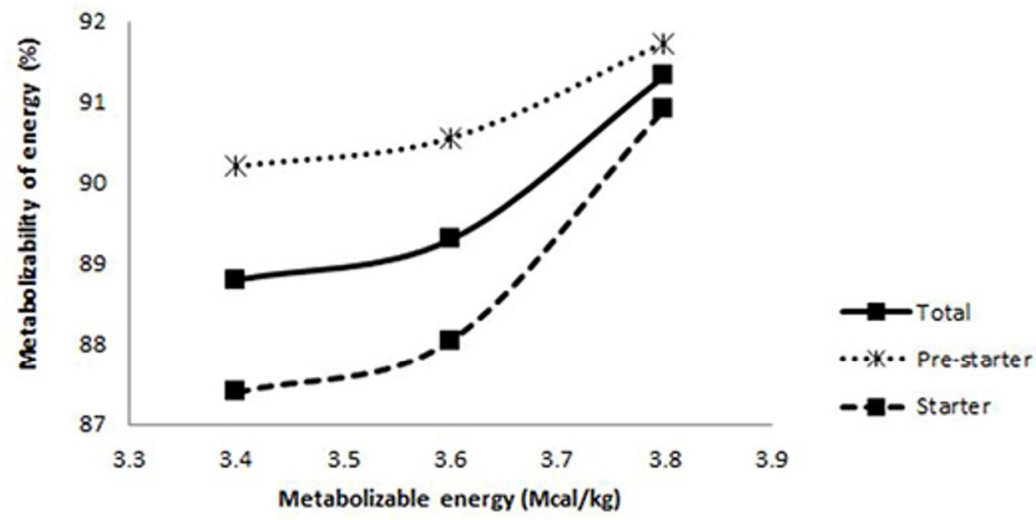

Figure 2. Linear effect of the dietary metabolizable energy levels on energy metabolizability: YPre-starter $=3.82 \mathrm{x}+77.08\left[\mathrm{r}^{2}=0.91\right] ; \mathrm{Y}_{\text {Starter }}=8.79 \mathrm{x}-57.13\left[\mathrm{r}^{2}=\right.$ $0.88]) ; Y_{\text {Total }}=6.31 \mathrm{x}-67.10\left[\mathrm{r}^{2}=0.89\right]$. Each point represents the mean of 11 piglets for the levels 3.40 and $3.80 \mathrm{Mcal} / \mathrm{kg}$ and 10 piglets for the level $3.60 \mathrm{Mcal} / \mathrm{kg} \mathrm{EM}$

By considering the concept that pigs eat to satisfy their energy needs, we adjusted the nutrients accordingly to the energy density augmentation. This adjustment assures that the animals may consume the same amount of energy and nutrients regardless of the energy density of the diets ${ }^{(24,25)}$. So, essentially nutrient to ME ratios were constant among three diets for each phase, mainly Lys 
which was 4.14 and $3.91 \mathrm{~g} / \mathrm{Mcal}$ in the pre-starter and starter period, respectively. By trying to maintain a constant Lys:ME ratio, we raised crude protein from 21 to $24 \%$. As we did not find any effect of the ME levels on the $\mathrm{N}$ excretion, it allows us to infer that the lower energy levels (3.40 and $3.60 \mathrm{Mcal} / \mathrm{kg}$ ) did not affect the metabolic utilization of nitrogen. Also, the increased crude protein did not result in an increased $\mathrm{N}$ excretion, which may reflect a correct balance in the amino acid profile in these diets.

There was a positive correlation between $\mathrm{WW}$ and $\mathrm{N}$ intake, retention, absorption $(\mathrm{P}<0.05, \mathrm{r}=0.61$; Table 3). Dietary ME levels correlated positively with $\mathrm{N}$ absorbed and retained $(\mathrm{P}<0.01 ; \mathrm{r}=0.40)$ and with energy metabolizability $(\mathrm{P}<0.01 ; \mathrm{r}=0.76)$. The direction and magnitude of the influence of the ME levels and WW corroborates the influence of the first factor on metabolizability of energy and $\mathrm{N}$ ingested, retained and absorbed. Also, it confirms the absence of WW effect on metabolizability of energy.

Table 3. Correlation of weaning weight and dietary metabolizable energy levels with variables related to nitrogen balance and energy metabolizability

\begin{tabular}{|c|c|c|c|c|}
\hline \multirow[t]{2}{*}{ Item } & \multicolumn{2}{|c|}{ Weaning weight } & \multicolumn{2}{|c|}{ Metabolizable energy } \\
\hline & Coefficient & P-value & Coefficient & P-value \\
\hline $\mathrm{N}$ intake & 0.613 & 0.000 & 0.304 & 0.090 \\
\hline $\mathrm{N}$ feces & 0.312 & 0.082 & -0.320 & 0.074 \\
\hline $\mathrm{N}$ urine & 0.333 & 0.062 & 0.213 & 0.242 \\
\hline $\mathrm{N}$ absorbed & 0.615 & 0.000 & 0.403 & 0.022 \\
\hline $\mathrm{N}$ retained & 0.611 & 0.000 & 0.401 & 0.023 \\
\hline $\mathrm{N}$ ret/abs & -0.009 & 0.960 & 0.046 & 0.803 \\
\hline Metabolizability of energy & -0.015 & 0.932 & 0.764 & 0.000 \\
\hline
\end{tabular}

\section{Conclusions}

Increased dietary metabolizable energy improved energy metabolizability and nitrogen retention, regardless of the weaning weight. Heavy weaned piglets had better efficiency in the use of the dietary nitrogen in terms of nitrogen absorption and retention.

\section{References}

1. Fix JS, Cassady JP, Holl JW, Herring WO, Culbertson MS, See M.T. Effect of piglet birth weight on survival and quality of commercial market swine. Livestock Science. 2010;132(1-3):98-106.

2. Damgaard LH, Rydhmer L, Lovendahl P, Grandinson K. Genetic parameters for within litter variation in piglet birth weight and change in within litter variation during suckling. Journal of Animal Science. 2003;81(3):604-610.

3. Milligan BN, Fraser D, Kramer DL. Within litter birth weight variation in the domestic pig and its relation to pre-weaning survival, weight gain and variation in weaning weights. Livestock Production Science. 2002;76(1-2):181-191.

4. Bérard J, Kreuzer M, Bee G. Effect of litter size and birth weight on growth, carcass and pork quality, and 
their relationship to postmortem proteolysis. Journal of Animal Science. 2008;86(9):2357-2368.

5. Dhakal S, Auckland C, Huang Y, Ambros B, Duke T, Wilson DG, Foxcroft G. Harding J. Uterine spaciousness during embryo and fetal development in multiparous sows improves birth weight and postnatal growth performance. Livestock Science. 2013;153(1-3):154-164.

6. Nissen P M, Oksbjerg N. Birth weight and postnatal dietary protein level affect performance, muscle metabolism and meat quality in pigs. Animal. 2011;5(9):1382-1389.

7. Pardo CE, Kreuzer M, Bee G. Effect of average litter weight in pigs on growth performance, carcass characteristics and meat quality of the offspring as depending on birth weight. Animal. 2013;7(11):1884-1892.

8. Le Bellego L, Noblet J. Performance and utilization of dietary energy and amino acids in piglets fed low protein diets. Livestock Production Science. 2002;76(1-2):45-58.

9. Trindade-Neto MA, Berto DA, Nyachoti CM, Schammass EA. Energy and amino acid content in phase 1 nursery diet: piglet performance and body chemical composition. Revista Brasileira de Zootecnia. 2010;39(6):1286-1294.

10. Arnaiz V, Ribeiro AML, Kessler AM, Raber M, Kuana S. Efecto del peso al destete, temperatura ambiental y energía metabolizable del pienso en lechones recién destetados. Revista Brasileira de Ciência Agrária. 2009;4(4):472-478.

11. Beaulieu AD, Aalhus JL, Williams N H, Patience J F. Impact of piglet birth weight, birth order, and litter size on subsequent growth performance, carcass quality, muscle composition, and eating quality of pork. Journal of Animals Science. 2010;88(8):2767-2778.

12. Oresanya TF, Beaulieu AD, Patience JF. Investigations of energy metabolism in weanling barrows: The interaction of dietary energy concentration and daily feed (energy) intake. Journal of Animal Science. 2008;86(2):348-363.

13. Rostagno HS, Albino LFT, Donzele JL. Tabelas brasileiras para aves e suínos: composição de alimentos e exigências nutricionais. 3nd ed. Viçosa: UFV; 2011. 252p.

14. Association of Official Analytical Chemistry - AOAC. Official methods of analysis of the Association of Official Analytical Chemists. 16nd ed. Arlington; 1995. 1115p.

15. Adeola O. Digestion and balance techniques in pigs. In: Lewis AJ, Southern, LL. Swine Nutrition. 1nd ed. Florida: Boca Raton; 2001. p. 903-916.

16. Prates ER. Técnicas de pesquisa em nutrição animal. 1nd ed. Porto Alegre: UFRGS; 2007. 414p.

17. Taylor AE, Jagger S, Toplis P, Wellock IJ, Miller HM. Are compensatory live weight gains observed in pigs following lysine restriction during the weaner phase? Livestock Science. 2013;157(1):200-209.

18. Václavková E, Daněk P, Rozkot M. The influence of piglet birth weight on growth performance. Research Pig Breed 2012;6(1):1-5.

19. Paredes SP, Kalbe C, Jansman AJM, Verstegen WA, van Hees HMJ, Losel D, Gerrits WJJ, Rehfeldt C. Predicted high-performing piglets exhibit more and larger skeletal muscle fibers. Journal of Animal Science. 2013;91(12):5589-5598.

20. Gondret F, Lefaucheur L, Juin H, Louveau I, Lebret B. Low birth weight is associated with enlarged muscle fiber area and impaired meat tenderness of the longissimus muscle in pigs. Journal of Animal Science. 2006;84(1):93-103.

21. Rehfeldt C, Fiedler I, Dietl G, Ender K. Myogenesis and postnatal skeletal muscle cell growth as influenced by selection. Livestock Production Science. 2000;66(2):177-188. 
22. Jones CK, Gabler NK, Main RG, Patience JF. Characterizing growth and carcass composition differences in pigs with varying weaning weight and post weaning performance. Journal of Animal Science. 2012;90(11):4072-4080.

23. Ribeiro AML, Farina G, Vieira MS, Perales VA, Kessler, AM. Energy utilization of light and heavy weaned piglets subjected to different dietary energy levels. Revista Brasileira de Zootecnia. 2016;45(9):532539.

24. Chiba LI, Lewis AJ, Peo Jr ER. Amino acid and energy interrelationships in pigs weighing 20 to 50 kilograms: I. Rate and efficiency of weight gain. Journal of Animal Science. 1991a;69(2):694-707.

25. Chiba LI, Lewis AJ, Peo Jr ER. 1991b. Amino acid and energy interrelationships in pigs weighing 20 to 50 kilograms: II. Rate and efficiency of protein and fat deposition. Journal of Animal Science. 1991b;69(2):708-718. 